\title{
Ground Water and River Quality Assessment for Some Heavy Metals and Physicochemical Parameters in Wukari Town, Taraba State, Nigeria
}

\author{
M. O. Aremu1 1 , O. J. Oko¹, C. Andrew ${ }^{1}$
}

${ }^{1}$ Department of Chemical Sciences, Federal University Wukari, PMB 1020, Wukari, Taraba State, Nigeria

\begin{abstract}
With a few to assessing the qualities of water sources in Wukari local government area (LGA), a study was conducted on ground water and rivers in two settlements at Wukari LGA. For this purpose, some heavy metals (cadmium, lead, arsenic, iron, copper, mercury and manganese) and physicochemical parameters (temperature, turbidity, suspended solids, total dissolved solids, conductivity, $\mathrm{pH}$, nitrate, phosphate, chloride, alkalinity, hardness and chemical/biochemical oxygen demand) were determined in water samples collected from hand-dug wells, boreholes and rivers in Puje and Avyi during wet and dry seasons using standard analytical techniques. The results showed that all the seven metals determined were detected and present at trace levels in all the water samples ranging from $0.001 \mathrm{ppm}(\mathrm{Hg})$ in well and borehole to $0.0768 \mathrm{ppm}(\mathrm{Fe})$ in river, and $0.001 \mathrm{ppm}(\mathrm{Hg})$ in borehole to $0.0763 \mathrm{ppm}(\mathrm{Fe})$ in river for Puje and Avyi, respectively. However, all the metals were found to have contained concentrations below the permissible safe level. The results further revealed that the levels of physicochemical parameters in the water samples for both wet and dry seasons are within the required standard limits set by World Health Organization (WHO) for drinking water. Nevertheless, source protection is recommended for the bodies of water for the benefit of Wukari people.
\end{abstract}

Keywords: Hand-dug Well, Borehole, River, Physicochemical Parameter, Wukari

\section{Introduction}

Water covers more than $70 \%$ of the earth though only $1 \%$ is available as a source of drinking. Accessibility and availability of fresh clean water is the key to sustainable development and an essential element in health, food production and poverty reduction [1]. The basic purposes for which water is domestically required include drinking, bathing, cooking, and general sanitation such as laundry, flushing of closets and other household chores [2]. Thus, an assured supply of water both qualitatively and quantitatively for these purposes greatly improves the social and economic activities of the people. Water can be obtained from many sources namely; oceans, rivers, lakes, springs, ponds, rain, as well as underground (borehole). Among the various sources of water, borehole water is known to be more appropriate and often meets the criteria of quality water as it is not exposed to the water pollutants associated with surface water [3]. However, underground water bodies are prone to contamination from both anthropogenic and natural activities, its vulnerability to contamination could be due to anthropogenic sources like broken septic tanks and pit toilets, sewage disposal on land, leachates from fertilizer applications, urban runoff, debris from erosion and polluted surface water [4]. Industrial growth, urbanization and the increasing use of synthetic organic substances can also have serious and adverse impacts on fresh water bodies due to the introduction of various pollutants such as organic compounds, heavy metals, agricultural waters, etc. [5, 6].

As many studies have shown, municipal refuse may increase heavy metal concentration in soil and underground water which may have effects on the host soils, crop and human health $[7,8]$. The increased use of metal containing fertilizers due to the agricultural revolution could lead to a continued rise of the concentration of metal pollutants in fresh water reservoirs due to water runoff. The vehicle emissions and tire and engine wear contribute sizeable concentrations of all metals particularly zinc and copper. Thus, significant correlations are found between traffic volumes and metal concentrations $[8$, 9]. Heavy metal contaminations of surface water have been reported by several workers [10 - 12]; studies have confirmed that heavy metals can directly influence behaviour by impairing mental and neurological function and altering metabolic

This article is published under the terms of the Creative Commons Attribution License 4.0

Author(s) retain the copyright of this article. Publication rights with Alkhaer Publications.

Published at: http://www.ijsciences.com/pub/issue/2017-05/

DOI: 10.18483/ijSci.1298; Online ISSN: 2305-3925; Print ISSN: 2410-4477 
processes. They induce impairment and dysfunction in blood and cardiovascular, endocrine, immune, nervous, reproductive and urinary systems [13].

Potable water supply to communities in Taraba State is the responsibility of the government which in most cases has been characterized by low productivity, small coverage and inefficient service delivery. Wukari local government area is one of the areas that partially enjoying potable water supply. Most rural dwellers therefore depend on various available water sources such as streams, rivers, hand-dug wells and boreholes. The qualities of these sources are generally not guaranteed and cases abound where health problems have risen as a result of consumers drinking from such sources (Table 1). Thus, for people of Wukari local government area of Taraba State, Nigeria to meet their daily water needs and household's requirement, they source water from a few privately owned boreholes and wells while majority of the people depend largely on the streams and rivers that traverse the land of the rural areas.

Table 1: Summary of water borne diseases occurrence as recoded at General Hospital Wukari, Taraba State

\begin{tabular}{|c|c|c|c|c|c|c|c|c|c|c|c|c|c|c|c|c|c|c|c|c|}
\hline \multicolumn{21}{|c|}{ Diseases Conditions } \\
\hline \multirow{2}{*}{$\begin{array}{c}\text { Category } \\
\text { of } \\
\text { Patients }\end{array}$} & \multicolumn{4}{|c|}{ Abdominal pains } & \multicolumn{4}{|c|}{ Typhoid fever } & \multicolumn{4}{|c|}{ Cholera } & \multicolumn{4}{|c|}{ Dysentery } & \multicolumn{4}{|c|}{ Diahorrea } \\
\hline & $\mathbf{M}$ & $\mathbf{F}$ & $\mathbf{C}$ & $\mathbf{T}$ & $\mathbf{M}$ & $\mathbf{F}$ & $\mathbf{C}$ & $\mathbf{T}$ & $\mathbf{M}$ & $\mathbf{F}$ & $\mathbf{C}$ & $\mathbf{T}$ & $\mathbf{M}$ & $\mathbf{F}$ & $\mathbf{C}$ & $\mathbf{T}$ & $\mathbf{M}$ & $\mathbf{F}$ & $\mathbf{C}$ & $\mathbf{T}$ \\
\hline Year: 2009 & 26 & 62 & 12 & 100 & 00 & 00 & 00 & 00 & 00 & 00 & 00 & 00 & 00 & 00 & 02 & 02 & 95 & 119 & 298 & 512 \\
\hline Year: 2010 & 13 & 09 & 00 & 22 & 01 & 00 & 00 & 01 & 00 & 00 & 82 & 82 & 00 & 02 & 01 & $\mathbf{0 3}$ & 51 & 54 & 106 & 211 \\
\hline Year: 2011 & 11 & 17 & 10 & 38 & 00 & 00 & 00 & 00 & 00 & 00 & 00 & 00 & 01 & 04 & 02 & $\mathbf{0 7}$ & 45 & 78 & 133 & 256 \\
\hline Year: 2012 & 11 & 24 & 09 & 44 & 02 & 05 & 01 & 08 & 00 & 00 & 00 & 00 & 00 & 00 & 02 & $\mathbf{0 2}$ & 34 & 44 & 74 & 152 \\
\hline Year: 2013 & 29 & 19 & 09 & 57 & 01 & 03 & 00 & 04 & 00 & 00 & 00 & 00 & 01 & 00 & 00 & 01 & 06 & 26 & 61 & 93 \\
\hline Total & 090 & 131 & 040 & 261 & 004 & 008 & 001 & 013 & 000 & 000 & 082 & 082 & 002 & 006 & 007 & 015 & 231 & 321 & 672 & 1,224 \\
\hline
\end{tabular}

$\mathbf{M}=$ Male; $\mathbf{F}=$ Female; $\mathbf{C}=$ Children; $\mathbf{T}=$ Total

Source: Record/Statistics Office of General Hospital Wukari, Taraba State, Nigeria

In order to safeguard the health of the people, it is important to monitor the heavy metals and physicochemical characteristics of water sources from rural and towns located in Wukari LGA so as to highlight the quality of water supply. This has motivated the researchers to assess some heavy metals (cadmium, lead, arsenic, iron, copper, mercury and manganese) and physicochemical parameters (temperature, turbidity, suspended solids, total dissolved solids, conductivity, $\mathrm{pH}$, nitrate, phosphate, chloride, alkalinity, handiness, chemical oxygen demand, dissolved oxygen, biochemical oxygen demand) present in the hand-dug wells, boreholes and rivers located in Puje and Avyi settlements at Wukari LGA.

\section{Materials and Methods \\ Study area}

Wukari town is the headquarters of Wukari local government area (LGA) in Taraba State, Nigeria. The LGA lies on the co-ordinates $7^{\circ} 51^{\prime} \mathrm{N} 9^{\circ} 47^{\prime} \mathrm{E}$ or $7.850^{\circ} \mathrm{N} 9.783^{\circ} \mathrm{E}$ covering an area of $4,308 \mathrm{~km}^{2}$ and having a population of 241,546 based on the 2006 census. It shares boundaries with Benue and
Nasarawa States of Nigeria (Fig. 1). The LGA is made up of different ethnic groups each with a distinct heritage; among the major tribes are: Jukun and Tiv while minor tribes such as Hausa, Fulani, Yoruba, Igbo, Idoma, Igalla, etc. are interspersed among the major tribes. It has a typical climate of the tropical zone because of its location. Its climate is quite pleasant with a mean annual temperature of $27.5^{\circ} \mathrm{C}$. The climate is characterized by two distinct seasons, dry and wet. The dry season spans from October to April while rainy season is from May to September. The months of December, January and February are cold due to Harmattan wind blowing across the local government area from the north-east of Nigeria. The sediments are generally comprised of sandstones, siltstone and forest soils which are rich in humus and very good for crop production. More than $70 \%$ of the inhabitants are predominantly farmers while few engage in fishing business. Most of the rural dwellers live on the shallow surface waters as source of potable water while people in Wukari town and smaller towns live on government owned and private boreholes, and deep wells as source of potable water. 


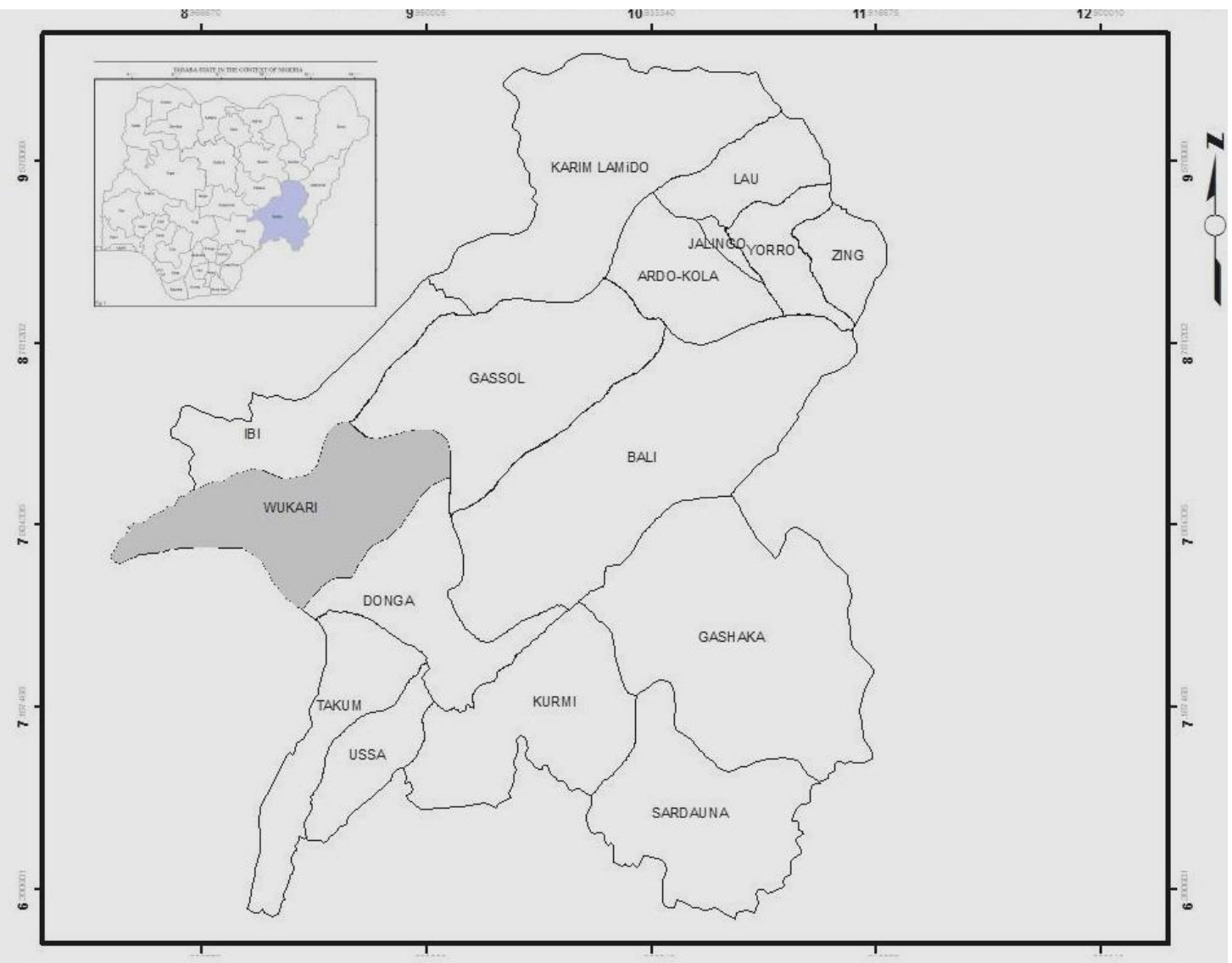

Fig. 1: Map of Taraba State showing the study area (Wukari LGA)

\section{Sample collection treatment and preservation}

Wukari town is divided into three Wards, namely; Puje, Avyi and Hospital but for the purpose of this study, water samples were taken from the hand-dug wells, boreholes and rivers located in Puje and Avyi Wards. The water samples were collected between May and September, 2015 for wet season; between November, 2015 to March, 2016 as dry season. Representative water sample was taken below the water surface from the river using $1 \mathrm{~L}$ acid leached polythene bottle. The samples from hand-dug wells and boreholes were collected using $1 \mathrm{~L}$ plastic container thoroughly washed and rinsed with $1: 1 \mathrm{HCl}$ and deionized water and further still with the water from the wells and boreholes at the point of collection. Five samples were collected from each of the well and borehole sites at $2 \mathrm{~h}$ intervals and mixed together to make a composite sample site. All the samples were kept in ice chests and transported to the laboratory where they were further preserved in refrigerator before analysis. All the chemicals were of analar grade.

\section{Mineral analysis}

Cadmium, lead, arsenic, iron, copper, mercury and manganese were determined in all the samples by using Perkin Elmer and Oak Brown atomic absorption spectrophotometer. The instrument settings and operational conditions were done in accordance with the manufacturer's specifications.

\section{Physicochemical analysis}

The physicochemical parameters determined include temperature turbidity, suspended solids, total dissolved solids, conductivity, $\mathrm{pH}$, nitrate, phosphate, chloride, alkalinity, hardness, chemical oxygen demand, dissolved oxygen and biochemical oxygen demand. Temperature, $\mathrm{pH}$ and conductivity were determined on the spot using the calibrated thermometer, microprocessor $\mathrm{pH}$ meter and Hanna electrical conductivity meter, respectively. Other parameters were determined using standard analytical methods [14]. All determinations were in triplicate.

\section{Statistical analysis}

The results obtained were subjected to statistical evaluation and presented in Tables $2-5$. Parameters evaluated were grand mean and standard deviation.

\section{Results and Discussion}

The concentrations of heavy metals in water samples collected from the hand-dug wells, boreholes and river located in Puje and Avyi settlements are presented in Tables 2 and 4. Cadmium, lead and 
mercury mean concentrations (ppm) in wells, boreholes and river during wet season for Puje settlement were $0.0023,0.0017$ and $0.0026 ; 0.0165$, 0.0032 and $0.2173 ; 0.0002,0.0001$ and 0.0005 , respectively (Table 2) whereas the values were $0.0020,0.0016$ and $0.0024 ; 0.0154,0.0027$ and $0.2114 ; 0.0002,0.0001$ and 0.0006 for Avyi settlement of the same season (Table 4). There was increase of $\mathrm{Cd}$ concentrations during dry season in Puje well and river samples by 14.8 and $7.1 \%$, respectively. $\mathrm{Hg}$ concentration also increased in the well sample by $33.3 \%$. The same trend was also observed in Avyi well and river samples which had increased of $28.6 \%$ and $4 \%$, respectively during dry season.

Table 2: Metal concentration (ppm) in water samples from Puje wells, boreholes and river Wet Season

\begin{tabular}{ccccccccccc}
\hline Mineral & PW1 & PW2 & PW3 & Mean & PB1 & PB2 & PB3 & Mean & River & USEPA in ppm \\
\hline $\mathrm{Cd}$ & 0.0023 & 0.0024 & 0.0023 & 0.0023 & 0.0016 & 0.0017 & 0.0019 & 0.0017 & 0.0026 & $0.2-1.80$ \\
$\mathrm{~Pb}$ & 0.0163 & 0.0168 & 0.0164 & 0.0165 & 0.0036 & 0.0027 & 0.0032 & 0.0032 & 0.2173 & 1.0 \\
$\mathrm{As}$ & 0.0016 & 0.0018 & 0.0019 & 0.0018 & 0.0008 & 0.0008 & 0.0009 & 0.0008 & 0.0041 & 0.50 \\
$\mathrm{Fe}$ & 0.0394 & 0.0391 & 0.0388 & 0.0391 & 0.0283 & 0.0275 & 0.0295 & 0.0284 & 0.0768 & 1.0 \\
$\mathrm{Cu}$ & 0.0013 & 0.0015 & 0.0014 & 0.0014 & 0.0003 & 0.0004 & 0.0004 & 0.0004 & 0.0052 & $2.0-4.0$ \\
$\mathrm{Hg}$ & 0.0002 & 0.0002 & 0.0002 & 0.0002 & 0.0001 & 0.0001 & 0.0001 & 0.0001 & 0.0005 & $0.025-0.50$ \\
$\mathrm{Mn}$ & 0.0206 & 0.0219 & 0.0211 & 0.0212 & 0.0092 & 0.0097 & 0.0096 & 0.0095 & 0.0374 & $0.02-0.10$ \\
\hline
\end{tabular}

\begin{tabular}{ccccccccccc}
\multicolumn{2}{l}{ Dry Season } \\
\hline Mineral & PW1 & PW2 & PW3 & Mean & PB1 & PB2 & PB3 & Mean & River & USEPA in ppm \\
\hline $\mathrm{Cd}$ & 0.0028 & 0.0028 & 0.0025 & 0.0027 & 0.0013 & 0.0013 & 0.0016 & 0.0014 & 0.0028 & $0.2-1.80$ \\
$\mathrm{~Pb}$ & 0.0183 & 0.0173 & 0.0184 & 0.0180 & 0.0026 & 0.0028 & 0.0028 & 0.0027 & 0.2119 & 1.0 \\
$\mathrm{As}$ & 0.0025 & 0.0023 & 0.0022 & 0.0023 & 0.0007 & 0.0006 & 0.0012 & 0.0008 & 0.0039 & 0.50 \\
$\mathrm{Fe}$ & 0.0395 & 0.0422 & 0.0363 & 0.0393 & 0.0263 & 0.0247 & 0.0241 & 0.0250 & 0.0713 & 1.0 \\
$\mathrm{Cu}$ & 0.0018 & 0.0019 & 0.0018 & 0.0018 & 0.0003 & 0.0006 & 0.0005 & 0.0005 & 0.0057 & $2.0-4.0$ \\
$\mathrm{Hg}$ & 0.0003 & 0.0002 & 0.0003 & 0.0003 & 0.0001 & 0.0001 & 0.0001 & 0.0001 & 0.0004 & $0.025-0.50$ \\
$\mathrm{Mn}$ & 0.0219 & 0.0237 & 0.0238 & 0.0231 & 0.0086 & 0.0086 & 0.0074 & 0.0082 & 0.0364 & $0.02-0.10$ \\
\hline
\end{tabular}

USEPA = United States Environmental Protection Agency [15]; PW1-3 = Puje well sampling points 1 to 3; PB1-3 $=$ Puje borehole sampling points 1 to 3 .

However, $\mathrm{Pb}$ concentrations in Avyi well, borehole and river increased by $24.1,526$ and $16.7 \%$, respectively during dry season while $\mathrm{Hg}$ only increased in well sample by $33.3 \%$. Although the concentrations of $\mathrm{Cd}, \mathrm{Pb}$ and $\mathrm{Hg}$ in all the water samples were below permissible level of USEPA guideline for drinking water (Tables 2 and 4), their presence at low concentration is known to be toxic. For instance, $\mathrm{Pb}$ has no known function in biochemical process. It can impair the nervous system and affect foetus, infants and children resulting in lowering of intelligent quotient (IQ) even at its lowest dose [16]. Long term exposure to $\mathrm{Cd}$ results in renal dysfunction and lung cancer, and also osteomalacia in the human and animals [10]. The inhalation of mercury vapour can produce harmful effects on the nervous, digestive and immune systems, lungs and kidneys, and may be fatal [12].

The mean concentration levels (ppm) of arsenic, copper and manganese in Puje wells, boreholes and river during wet season were $0.0018,0.0008$ and $0.00041 ; 0.0014,0.0004$ and $0.0052 ; 0.0212,0.0095$ and 0.0374 , respectively (Table 2 ) whereas the values were $0.0014,0.0008$ and $0.0041 ; 0.0012,0.0003$ and $0.0048 ; 0.0241,0.0916$ and 0.0422 for Avyi settlement of the same season (Table 4). There was increase in As concentration during dry season in Puje well by $21.7 \%$ but its concentration decrease by $4.9 \%$ in Puje river. But $\mathrm{Cu}$ recorded increase during dry season in all water samples (Table 2). Arsenic has been implicated in lung cancer, especially when the arsenic compound inhaled is of low solubility. It has also been found to have an effect on the liver by causing a disease termed cirrhosis and a rare form of liver cancer called haemongioendothelioma [17]. Copper and manganese are essential metals and play an important role in enzyme activity if they are present at moderate level. Manganese has been implicated in neurological problems, especially when inhaled. The $\mathrm{As}, \mathrm{Cu}$ and $\mathrm{Mn}$ contents in the present study for all the water samples for both seasons (Tables 2 and 4) were found to be within the permissible limits of USEPA standard. Similar observation was made by the Federal Ministry of Environment on water standards for aquatic life to which most metals conform [18]. The high iron content and its wide distribution throughout the sampling points (Tables 2 and 4) reflect its presence at high concentration in Nigerian soils [19-22].

Iron is one of the essential compounds of 
haemoglobin which is responsible for the transport of oxygen in the body. It also occurs in the prosthetic group of the cytochromes which function in election transport and in some enzumes like the dehydrogenases [23]. It also facilitates the oxidation of carbohydrates, proteins and fats. Iron therefore contributes significantly to the prevention of anaemia, which is widespread in developing countries like Nigeria [24]. The iron contents in all the water samples (Tables 2 and 4) are lower than USEPA value of $1.0 \mathrm{ppm}$ for drinking water [15]. This is not unacceptable to the consumers but give rise to iron-dependent bacteria which in-turn can cause further deterioration in the quality of water through the development of climes and/or objectionable odour. Moreover, because a metal concentration in the aquatic environment is low and considered to be naturally occurring or background, does not mean that the concentration could not cause adverse ecological effects [15]. The presence of one metal can significantly affect the impact that another metal may have on an organism. The effect can be synergistic, additive or antagonistic [25]. The variation in results of individual heavy metals obtained between the wet and dry seasons may be due to run-offs (rainy season), geological formations of the sample locations and reduction in the volume of water due to high solar radiation and temperature (dry season) $\quad[10, \quad 26]$.

Table 3: Levels of physicochemical parameters in the water samples from Puje wells, boreholes and river Wet Season

\begin{tabular}{|c|c|c|c|c|c|c|c|c|c|c|c|}
\hline Parameter & PW1 & PW2 & PW3 & Mean & PBl & PB2 & PB3 & Mean & River & Permissible criteria & Desirable criteriaa $^{2}$ \\
\hline Temperature $\left({ }^{\circ} \mathrm{C}\right)$ & $28.6(0.20)$ & $28.0(0.10)$ & $28.0(0.10)$ & 28.20 & $28.0(0.30)$ & $28.0(0.20)$ & $28.0(0.50)$ & 28.0 & $28.4(0.20)$ & $<40$ & $<40$ \\
\hline Turbidity (NTU) & $8(0.60)$ & $1(0.75)$ & $1(0.00)$ & 3.23 & $1(0.00)$ & 0 & $2(0.00)$ & 1.0 & $2(0.50)$ & $\mathrm{NA}$ & $\mathrm{NA}$ \\
\hline Suspended solids $\left(\mathrm{mgL}^{-1}\right)$ & $4(0.00)$ & 0 & 0 & 1.33 & 0 & 0 & $1(0.00)$ & 0.33 & $1(0.10)$ & $\mathrm{NA}$ & $\mathrm{NA}$ \\
\hline $\operatorname{TDS}\left(\mathrm{mgL}^{-1}\right)$ & $27.1(2.25)$ & $25.1(1.01)$ & $26.8(2.31)$ & 26.33 & $27.1(2.11)$ & $27.9(3.18)$ & $39.4(2.16)$ & 31.47 & $33.2(3.25)$ & 500 & $<200$ \\
\hline Conductivity $\left(\mu \mathrm{Scm}^{-1}\right)$ & $80.1(4.25)$ & $67.1(0.13)$ & $68.0(2.11)$ & 71.73 & $75.2(1.21)$ & $76.0(1.68)$ & $94.2(5.15)$ & 81.8 & $77.2(5.69)$ & 5.00 & 5.00 \\
\hline $\mathrm{pH}$ & $7.74(0.25)$ & $7.24(2.01)$ & $7.44(1.10)$ & 7.47 & $8.42(0.21)$ & $7.64(2.15)$ & $7.38(0.55)$ & 7.81 & $7.30(2.10)$ & $6.0-8.5$ & $6.0-8.5$ \\
\hline Nitrate $\left(\mathrm{mgL}^{-1}\right)$ & $28.0(2.01)$ & $26.0(4.10)$ & $29.1(2.10)$ & 27.7 & $26.8(1.50)$ & $24.0(2.15)$ & $26.8(1.11)$ & 25.87 & $32.0(2.00)$ & $<10$ & Virtually absent \\
\hline Phosphate (mgL-1) & $96(0.20)$ & $0.72(2.150$ & $1.04(2.10)$ & 0.91 & $0.98(0.15)$ & $1.02(0.59)$ & $1.06(0.26)$ & 1.02 & $1.26(0.20)$ & $\mathrm{NA}$ & NA \\
\hline Chloride $\left(\mathrm{mgL}^{-1}\right)$ & $.4(4.15)$ & $27.1(0.35)$ & $28.6(1.22)$ & 29.03 & $26.7(1.35)$ & $27.1(4.20)$ & $51.9(2.50)$ & 35.23 & $51.7(3.20)$ & 2.50 & $<25$ \\
\hline Alkalinity $\left(\mathrm{mgL}^{-1}\right)$ & $8.80(1.15)$ & $8.20(1.00)$ & $8.80(0.310)$ & 8.60 & $10.80(0.28)$ & $9.60(0.55)$ & $8.60(0.55)$ & 9.67 & $8.10(4.15)$ & $30-500$ & $30-500$ \\
\hline Hardness $\left(\mathrm{mgL}^{-1}\right)$ & $100(1.10)$ & $80(3.10)$ & $100(2.41)$ & 93.33 & $100(3.15)$ & $100(5.40)$ & $160(3.56)$ & 120 & & 200 & $<200$ \\
\hline $\mathrm{COD}\left(\mathrm{mgL}^{-1}\right)$ & $96(0.06)$ & $92(0.10$ & $98(1.20)$ & 95.33 & $72(1.650$ & $54(4.58)$ & $52(2.15)$ & 59.33 & $128(3.25)$ & NA & $\mathrm{NA}$ \\
\hline $\mathrm{DO}_{2}\left(\mathrm{mgL}^{-1}\right)$ Day 1 & $5.0(0.21)$ & $5.2(0.30)$ & $5.1(0.60)$ & 5.1 & $5.0(1.32)$ & $5.6(0.35)$ & $5.1(0.16)$ & 5.2. & & NA & NA \\
\hline $\mathrm{DO}_{2}\left(\mathrm{mgL}^{-1}\right) \mathrm{Day}_{5}$ & & & $4.3(0.31)$ & 4.3 & $4.4(2.10)$ & $5.1(2.32)$ & & 4.73 & & $\mathrm{NA}$ & $\mathrm{NA}$ \\
\hline $\mathrm{BOD}\left(\mathrm{mgL}^{-1}\right)$ & $48(0.55)$ & $46(4.20)$ & $49(2.01)$ & 47.67 & $36(2.15)$ & $27(1.65)$ & $26(0.32)$ & 29.67 & $64(2.50)$ & 9.00 & $<9.00$ \\
\hline
\end{tabular}

Dry Season

\begin{tabular}{|c|c|c|c|c|c|c|c|c|c|c|c|}
\hline Parameter & PWl & PW2 & PW3 & Mean & PBl & PB2 & PB3 & Mean & River & Permissible criteria & Desirable criteria $^{2}$ \\
\hline Temperature $\left({ }^{\circ} \mathrm{C}\right)$ & $29.1(0.45)$ & $29.7(2.05)$ & $30.0(3.26)$ & 29.60 & $29.0(2.65)$ & $29.0(3.20)$ & $29.0(1.86)$ & 29.00 & $30.0(2.30)$ & $<40$ & $<40$ \\
\hline Turbidity (NTU) & 0 & 0 & $1(0.00)$ & 0.33 & $1(0.00)$ & 0 & $1(0.56)$ & 0.67 & $10(5.05)$ & $\mathrm{NA}$ & $\mathrm{NA}$ \\
\hline Suspended solids $\left(\mathrm{mgL}^{-1}\right)$ & 0 & 0 & $1(0.65)$ & 0.33 & 0 & 0 & 0 & 0 & $7(0.23)$ & $\mathrm{NA}$ & $\mathrm{NA}$ \\
\hline $\operatorname{TDS}\left(\mathrm{mgL}^{-1}\right)$ & $27.9(2.40)$ & $26.7(5.55)$ & $29.1(5.05)$ & 27.90 & $27.4(0.40)$ & $28.0(3.90)$ & $39.8(2.34)$ & 31.73 & $51.6(5.06)$ & 500 & $<200$ \\
\hline Conductivity $\left(\mu \mathrm{Scm}^{-1}\right)$ & $81.4(6.90)$ & $67.1(6.20)$ & $70.1(2.05)$ & 72.87 & $76.0(6.05)$ & $76.4(3.05)$ & $95.0(3.19)$ & 82.47 & $82.6(8.45)$ & 5.00 & 5.00 \\
\hline $\mathrm{pH}$ & $6.40(2.03)$ & $6.62(1.03)$ & $6.64(1.05)$ & 6.55 & $7.40(0.05)$ & $7.74(0.06)$ & $7.60(0.26)$ & 7.58 & $7.28(1.06)$ & $6.0-8.5$ & $6.0-8.5$ \\
\hline Nitrate $\left(\mathrm{mgL}^{-1}\right)$ & $21.0(4.12)$ & $20.1(2.06)$ & $20.7(3.55)$ & 20.60 & $21.6(3.05)$ & $20.0(4.05)$ & $22.4(5.80)$ & 21.33 & $30.4(4.85)$ & $<10$ & Virtually absent \\
\hline Phosphate $\left(\mathrm{mgL}^{-1}\right)$ & $1.12(0.12)$ & $0.81(0.40)$ & $1.28(0.12)$ & 1.07 & $1.04(0,02)$ & $1.18(2.05)$ & $1.14(3.90)$ & 1.12 & $1.42(4.20)$ & $\mathrm{NA}$ & NA \\
\hline Chloride $\left(\mathrm{mgL}^{-1}\right)$ & $37.0(4.07)$ & $29.7(6.20)$ & $30.7(5.56)$ & 32.47 & $27.1(0.89)$ & $30.7(2.90)$ & $55.0(5.03)$ & 37.60 & $57.1(5.26)$ & 2.50 & $<25$ \\
\hline Alkalinity $\left(\mathrm{mgL}^{-1}\right)$ & $8.00(1.98)$ & $7.60(0.21)$ & $7.60(2.04)$ & 7.33 & $8.40(4.00)$ & $10.20(0.23)$ & $9.60(4.12)$ & 9.40 & $8.00(2.35)$ & $30-500$ & $30-500$ \\
\hline Hardness $\left(\mathrm{mgL}^{-1}\right)$ & $120(4.23)$ & $100(6.89)$ & $140(1.01)$ & 1.20 & $120(9.08)$ & $120(0.98)$ & $180(8.34)$ & 140 & $120(0.28)$ & 200 & $<200$ \\
\hline $\operatorname{COD}\left(\mathrm{mgL}^{-1}\right)$ & $76(3.90)$ & $80(0.32)$ & $68(0.00)$ & 74.67 & $60(0.00)$ & $40(3.00)$ & $44(0.00)$ & 48 & $136(1.01)$ & $\mathrm{NA}$ & $\mathrm{NA}$ \\
\hline $\mathrm{DO}_{2}\left(\mathrm{mgL}^{-1}\right)$ Day 1 & $5.1(2.45)$ & $5.4(0.57)$ & $5.3(2.03)$ & 5.27 & $5.9(0.89)$ & $6.0(3.09)$ & $5.7(2.10)$ & 5.87 & $5.8(0.84)$ & $\mathrm{NA}$ & $\mathrm{NA}$ \\
\hline $\mathrm{DO}_{2}\left(\mathrm{mgL}^{-1}\right)$ Day 5 & $4.5(2.13)$ & $4.7(0.35)$ & $4.7(1.01$ & 4.63 & $5.4(5.65)$ & $5.7(0.43)$ & $4.9(0.03)$ & 5.33 & $4.7(0.05)$ & NA & $\mathrm{NA}$ \\
\hline $\mathrm{BOD}\left(\mathrm{mgL}^{-1}\right)$ & $38(6.68)$ & $40(6.43)$ & $34(0.00)$ & 37.33 & $30(5.04)$ & $20(3.05)$ & $22(5.21)$ & 24 & $68(5.12)$ & 9.00 & $<9.00$ \\
\hline
\end{tabular}

Numbers in parenthesis are standard deviations of triplicate determinations. Notes: ND= Not detected; NA= Not Available; ${ }^{\text {a Source }}=$ Report of the Committee on water quality criteria, Federal Water Pollution Administration, US Department of Interior, Washington DC [14, 15] and Federal Protection Agency, Nigeria [18].

Table 4: Metal concentration (ppm) in water samples from Avyi wells, boreholes and river Wet Season

\begin{tabular}{|c|c|c|c|c|c|c|c|c|c|c|}
\hline Mineral & AWl & AW2 & AW3 & Mean & $\mathrm{ABl}$ & AB2 & AB3 & Mean & River & USEPA in $\mathrm{ppm}$ \\
\hline $\mathrm{Cd}$ & 0.0018 & 0.0022 & 0.0021 & 0.0020 & 0.0015 & 0.0016 & 0.0017 & 0.0016 & 0.0024 & $0.0-1.80$ \\
\hline $\mathrm{Pb}$ & 0.0154 & 0.0152 & 0.0156 & 0.0154 & 0.0027 & 0.0026 & 0.0029 & 0.0027 & 0.2114 & 1.0 \\
\hline As & 0.0014 & 0.0015 & 0.0014 & 0.0014 & 0.0009 & 0.0007 & 0.0008 & 0.0008 & 0.0041 & 0.50 \\
\hline $\mathrm{Fe}$ & 0.0377 & 0.0384 & 0.0382 & 0.0381 & 0.0269 & 0.0266 & 0.0257 & 0.0264 & 0.0763 & 1.0 \\
\hline $\mathrm{Cu}$ & 0.0012 & 0.0012 & 0.0011 & 0.0012 & 0.0003 & 0.0003 & 0.0003 & 0.0003 & 0.0048 & $2.0-4.0$ \\
\hline $\mathrm{Hg}$ & 0.0002 & 0.0002 & 0.0002 & 0.0002 & 0.0001 & 0.0001 & 0.0001 & 0.0001 & 0.0006 & $0.025-0.50$ \\
\hline $\mathrm{Mn}$ & 0.0236 & 0.0241 & 0.0246 & 0.0241 & 0.0113 & 0.0119 & 0.0116 & 0.0916 & 0.0422 & $0.02-0.10$ \\
\hline
\end{tabular}


Ground Water and River Quality Assessment for Some Heavy Metals and Physicochemical Parameters in Wukari Town, Taraba State, Nigeria

\section{Dry Season}

\begin{tabular}{ccccccccccc}
\hline Mineral & AWl & AW2 & AW3 & Mean & AB1 & AB2 & AB3 & Mean & River & USEPA in ppm \\
\hline $\mathrm{Cd}$ & 0.0026 & 0.0028 & 0.0029 & 0.0028 & 0.0015 & 0.0015 & 0.0016 & 0.0015 & 0.0025 & $0.2-1.80$ \\
$\mathrm{~Pb}$ & 0.0198 & 0.0211 & 0.0199 & 0.0203 & 0.0052 & 0.0062 & 0.0056 & 0.0057 & 0.2539 & 1.0 \\
$\mathrm{As}$ & 0.0032 & 0.0035 & 0.0031 & 0.0033 & 0.0009 & 0.0008 & 0.0009 & 0.0009 & 0.0049 & 0.50 \\
$\mathrm{Fe}$ & 0.0452 & 0.0456 & 0.0471 & 0.0460 & 0.0288 & 0.0269 & 0.0296 & 0.0284 & 0.0749 & 1.0 \\
$\mathrm{Cu}$ & 0.0029 & 0.0027 & 0.0026 & 0.0027 & 0.0006 & 0.0005 & 0.0008 & 0.0006 & 0.0072 & $2.0-4.0$ \\
$\mathrm{Hg}$ & 0.0003 & 0.0004 & 0.0003 & 0.0003 & 0.0001 & 0.0001 & 0.0001 & 0.0001 & 0.0004 & $0.025-0.50$ \\
$\mathrm{Mn}$ & 0.0244 & 0.0251 & 0.0253 & 0.0249 & 0.0091 & 0.0105 & 0.0115 & 0.0104 & 0.0386 & $0.02-0.10$
\end{tabular}

USEPA = United States Environmental Protection Agency [15]; AW1-3 = Avyi well sampling points 1 to 3; AB1-3 $=$ Avyi borehole sampling points 1 to 3 .

Table 5: Levels of physicochemical parameters in the water samples from Avyi wells, boreholes and river Wet Season

\begin{tabular}{|c|c|c|c|c|c|c|c|c|c|c|c|}
\hline Parameter & AWl & AW2 & AW3 & Mean & AB1 & AB2 & AB3 & Mean & River & Permissible criteria ${ }^{2}$ & Desirable criteria \\
\hline Temperature $\left({ }^{\circ} \mathrm{C}\right)$ & $28.1(2.05)$ & $28.0(4.50)$ & $28.0(2.43)$ & 28.03 & $28.0(4.04)$ & $28.3(2.43)$ & $28.4(4.54)$ & 28.23 & $28.1(2.89)$ & $<40$ & $<40$ \\
\hline Turbidity (NTU) & $4(0.00)$ & $2(0.00)$ & $2(0.00)$ & 2.67 & 0 & $12(4.05)$ & $22(2.04)$ & 11.33 & 0 & $\mathrm{NA}$ & $\mathrm{NA}$ \\
\hline Suspended solids $\left(\mathrm{mgL}^{-1}\right)$ & $2(0.20)$ & $1(0.02)$ & 0 & 1.00 & 0 & $7(2.03)$ & $14(3.04)$ & 7.00 & 0 & NA & $\mathrm{NA}$ \\
\hline $\operatorname{TDS}\left(\mathrm{mgL}^{-1}\right)$ & $25(0.45)$ & $21.7(0.43)$ & $20.9(0.32)$ & 22.53 & $19.4(3.02)$ & $27.1(3.05)$ & $37.8(4.05)$ & 28.10 & 30.0 & 500 & $<200$ \\
\hline Conductivity $\left(\mu \mathrm{Scm}^{-1}\right)$ & $71.9(3.45)$ & $69.2(6.07)$ & $61.0(0.43)$ & 67.37 & $60.1(5.80)$ & $70.6(0.22)$ & $88.4(3.05)$ & 73.03 & 71.8 & 5.00 & 5.00 \\
\hline $\mathrm{pH}$ & $7.38(3.24)$ & $7.66(0.45)$ & $7.58(0.34)$ & 7.54 & $7.61(2.04)$ & $7.68(1.05)$ & $7.00(0.36)$ & 7.43 & 7.61 & $6.0-8.5$ & $6.0-8.5$ \\
\hline Nitrate $\left(\mathrm{mgL}^{-1}\right)$ & $26.0(6.45)$ & $24.5(0.45)$ & $20.4(0.45)$ & 23.63 & $20.1(2.05)$ & $28.4(2.44)$ & $30.6(0.35)$ & 26.37 & 32.8 & $<10$ & Virtually absent \\
\hline Phosphate $\left(\mathrm{mgL}^{-1}\right)$ & $0.70(0.05)$ & $0.67(0.00)$ & $0.44(0.03)$ & 0.60 & $0.39(0.45)$ & $0.77(0.00)$ & $1.16(0.30)$ & 0.77 & 0.96 & $\mathrm{NA}$ & $\mathrm{NA}$ \\
\hline Chloride $\left(\mathrm{mgL}^{-1}\right)$ & $26.1(0.00)$ & $21.4(0.45)$ & $20.0(0.00)$ & 22.50 & $19.7(2.05)$ & $27.1(5.00)$ & $37.9(6.07)$ & 28.23 & 43.7 & 2.50 & $<25$ \\
\hline Alkalinity $\left(\mathrm{mgL}^{-1}\right)$ & $9.20(0.34)$ & $10.40(0.34)$ & $9.80(0.44)$ & 9.80 & $9.40(0.05)$ & $9.40(3.55)$ & $8.20(3.23)$ & 9.00 & 9.40 & $30-500$ & $30-500$ \\
\hline Hardness (mgL $\left.{ }^{-1}\right)$ & $100(5.20)$ & $80(8.88)$ & $60(6.55)$ & 80.00 & $60(0.66)$ & $80(5.34)$ & $120(9.89)$ & 86.67 & 80 & 200 & $<200$ \\
\hline $\mathrm{COD}\left(\mathrm{mgL}^{-1}\right)$ & $98(5.99)$ & $76(6.77)$ & $48(0.00)$ & 74.00 & $44(2.44)$ & $52(4.00)$ & $60(0.00)$ & 52.00 & 116 & $\mathrm{NA}$ & $\mathrm{NA}$ \\
\hline $\mathrm{DO}_{2}\left(\mathrm{mgL}^{-1}\right)$ Day 1 & $4.6(2.30)$ & $4.4(0.010$ & $4.9(0.54)$ & 4.63 & $5.0(0.05)$ & $4.6(0.34)$ & $4.4(0.12)$ & 4.67 & 6.0 & NA & $\mathrm{NA}$ \\
\hline $\mathrm{DO}_{2}\left(\mathrm{mgL}^{-1}\right)$ Day 5 & $3.7(0.45)$ & $3.8(0.55)$ & $4.2(0.45)$ & 3.90 & $4.6(0.35)$ & $4.2(0.40)$ & $3.9(0.12)$ & 4.23 & 5.1 & $\mathrm{NA}$ & $\mathrm{NA}$ \\
\hline $\mathrm{BOD}\left(\mathrm{mgL}^{-1}\right)$ & $49(0.55)$ & $38(0.00)$ & $42(0.44)$ & 43.00 & $22(2.05)$ & $26(3.80)$ & $30(3.04)$ & 26.00 & 58 & 9.00 & $<9.00$ \\
\hline
\end{tabular}

\section{Dry Season}

\begin{tabular}{|c|c|c|c|c|c|c|c|c|c|c|c|}
\hline Parameter & AWl & AW2 & AW3 & Mean & ABl & AB2 & AB3 & Mean & River & Permissible criteria ${ }^{a}$ & Desirable criteria $^{2}$ \\
\hline Temperature. $\left({ }^{\circ} \mathrm{C}\right)$ & $29.1(2.05)$ & $29.0(0.06)$ & $29.0(0.69)$ & 29.03 & $29.0(0.43)$ & $29.1(1.01)$ & $29.2(0.43)$ & 29.10 & $30.7(4.05)$ & $<40$ & $<40$ \\
\hline Turbidity (NTU) & 2 & $1(0.01)$ & $1(0.00)$ & 1.33 & 0 & 10 & $17(2.10)$ & 9.00 & $26(0.05)$ & $\mathrm{NA}$ & $\mathrm{NA}$ \\
\hline Suspended solids $\left(\mathrm{mgL}^{-1}\right)$ & $1(0.00)$ & 0 & 0 & 0.33 & 0 & $5(0.00)$ & $10(0.00)$ & 5.00 & $17(4.05)$ & $\mathrm{NA}$ & $\mathrm{NA}$ \\
\hline $\operatorname{TDS}\left(\mathrm{mgL}^{-1}\right)$ & $26.1(5.04)$ & $23.8(1.04)$ & $21.4(2.04)$ & 23.77 & $21.0(3.02)$ & $29.7(5.34)$ & $39.1(2.00)$ & 29.93 & $47.1(0.34)$ & 500 & $<200$ \\
\hline Conductivity $\left(\mu \mathrm{Scm}^{-1}\right)$ & $72.8(4.05)$ & $70.4(8.09)$ & $67.1(4.05)$ & 70.10 & $64.7(0.22)$ & $71.2(2.42)$ & $89.1(2.18)$ & 75.00 & $78.9(2.06)$ & 5.00 & 5.00 \\
\hline $\mathrm{pH}$ & $6.41(0.05)$ & $6.42(0.30)$ & $7.60(0.33)$ & 6.81 & $7.64(0.55)$ & $7.84(2.05)$ & $7.61(1.23)$ & 7.70 & $7.84(0.25)$ & $6.0-8.5$ & $6.0-8.5$ \\
\hline Nitrate $\left(\mathrm{mgL}^{-1}\right)$ & $25.8(4.05)$ & $20.1(6.40)$ & $18.4(1.05)$ & 21.43 & $16.0(0.55)$ & $24.2(0.23)$ & $26.2(6.25)$ & 22.13 & $40.0(2.05)$ & $<10$ & Virtually absent \\
\hline Phosphate $\left(\mathrm{mgL}^{-1}\right)$ & $0.81(0.34)$ & $0.71(0.01)$ & $0.47(3.04)$ & 0.66 & $0.41(2.88)$ & $0.79(0.20)$ & $1.18(0.02)$ & 0.79 & $1.04(2.05)$ & $\mathrm{NA}$ & NA \\
\hline Chloride $\left(\mathrm{mgL}^{-1}\right)$ & $29.0(2.04)$ & $23.0(2.04)$ & $21.7(2.05)$ & 24.57 & $21.0(1.01)$ & $29.7(3.20)$ & $40.1(0.00)$ & 30.27 & $51.4(3.05)$ & 2.50 & $<25$ \\
\hline Alkalinity $\left(\mathrm{mgL}^{-1}\right)$ & $9.0(3.04)$ & $10.0(2.03)$ & $10.00(2.02)$ & 9.67 & $10.20(0.46)$ & $10.40(1.01)$ & $10.00(0.00)$ & 10.20 & $10.20(2.05)$ & $30-500$ & $30-500$ \\
\hline Hardness (mgL $\left.{ }^{-1}\right)$ & $120(3.05)$ & $120(5.05)$ & $80(0.00)$ & 106.67 & $80(8.05)$ & $80(0.00)$ & $140(2.55)$ & 100 & $160(8.05)$ & 200 & $<200$ \\
\hline $\mathrm{COD}\left(\mathrm{mgL}^{-1}\right)$ & $78(0.05)$ & $62(0.12)$ & $78(4.03)$ & 72.67 & $40(0.00)$ & $40(6.34)$ & $48(4.55)$ & 42.67 & $114(0.00)$ & $\mathrm{NA}$ & $\mathrm{NA}$ \\
\hline $\mathrm{DO}_{2}\left(\mathrm{mgL}^{-1}\right)$ Day 1 & $4.8(4.05)$ & $4.6(2.03)$ & $5.0(3.04)$ & 4.80 & $5.3(0.11)$ & $4.9(0.33)$ & $4.8(2.99)$ & 5.0 & $5.7(0.34)$ & $\mathrm{NA}$ & $\mathrm{NA}$ \\
\hline $\mathrm{DO}_{2}\left(\mathrm{mgL}^{-1}\right)$ Day 5 & $4.1(3.05)$ & $4.1(2.03)$ & $4.4(0.12)$ & 4.20 & $5.0(2.04)$ & $4.6(0.44)$ & $4.4(4.55)$ & 4.67 & $4.8(0.23)$ & $\mathrm{NA}$ & $\mathrm{NA}$ \\
\hline $\mathrm{BOD}\left(\mathrm{mgL}^{-1}\right)$ & $39(5.06)$ & $31(2.04)$ & $34(3.04)$ & 34.67 & $20(5.29)$ & $20(0.56)$ & $24(3.25)$ & 21.33 & $56(4.01)$ & 9.00 & $<9.00$ \\
\hline
\end{tabular}

Numbers in parenthesis are standard deviations of triplicate determinations. Notes: ND= Not detected; NA= Not Available; ${ }^{\text {a Source }}=$ Report of the Committee on water quality criteria, Federal Water Pollution Administration, US Department of Interior, Washington DC [14, 15] and Federal Protection Agency, Nigeria [18].

Physicochemical parameter levels of water samples collected at wet and dry seasons from the wells, boreholes and rivers located in Puje and Avyi settlements are displayed in Tables 3 and 5. The mean temperature values in both wet and dry seasons for all the water samples ranged from 28.0 to $30.0^{\circ} \mathrm{C}$ (Table 3) while the values ranged from 28.0 to $30.7^{\circ} \mathrm{C}$
(Table 5). The values are higher than WHO recommended value of $25^{\circ} \mathrm{C}$ [27]. The $\mathrm{pH}$ is a function of the dissolved materials in water and should be less than 8.50 (Tables 3 and 5). The $\mathrm{pH}$ values for wet and dry seasons ranged between 6.55 and 7.81 (Puje) and 6.81 to 7.84 (Avyi). It implies that the water samples may be favourable to the 
existence of bacteria whenever the $\mathrm{pH}$ is greater than 7. Turbidity is a function of the suspended matter in water which ranged from colloidal to coarse dispersion while chemical oxygen demand (COD) or biochemical oxygen demand (BOD) is used for estimating the concentration of organic matter in waste water. The values of turbidity, COD and BOD obtained in this report (Tables 3 and 5) showed that the water samples were not seriously polluted because high value of COD or BOD implies that such water will have objectionable odour, render the water unfit for domestic purpose and reduce oxygen available for aquatic organisms [28]. Phosphate and nitrate ions were present in all the water samples collected from the two settlements for both wet and dry seasons and the mean values are higher than permissible criteria (Tables 3 and 5). Phosphorus and nitrogen occur in natural water and in waste water almost solely as phosphates and nitrates, respectively. The high concentrations of phosphate and nitrate could indicate pollution and are largely responsible for eutrophic conditions. Chlorides occur in natural water at varying concentrations depending on the geochemical conditions. Chlorides are the most stable components in water with concentration that is unaffected by most natural physicochemical or biochemical processes; their amount in water is useful measure in water samples. Chloride can range from $<10 \mathrm{mgL}^{-1}$ to $>2500 \mathrm{mgL}^{-1}$ (in sea water). Conductivity with range values of $71.73 \mu \mathrm{Scm}^{-1}$ in well (wet season) and $82.6 \mu \mathrm{Scm}^{-1}$ in river (dry season) (Table 3); $67.37 \mu \mathrm{Scm}^{-1}$ in well (wet season) and $78.9 \mu \mathrm{Scm}^{-1}$ in river (dry season) (Table 5) fall within WHO recommended value of $1000 \mu \mathrm{Scm}^{-1}$.

\section{Conclusion}

This work has presented data on the concentrations of some heavy metals and physicochemical parameters of water samples from hand-dug wells, boreholes and rivers located in Puje and Avyi settlements of Wukari local government area, Taraba State, Nigeria. This being the most detailed study of its kind on the area. The results showed that the heavy metals and most water quality parameters investigated for the water samples from the three sources are within the WHO/USEPA standards. Thus, the water sources are acceptable water supply to the community. However, there is a need to ensure that these sources are protected not only from flood but also from dumping of waste and grazing of animals as it is common around many water sources. This work therefore will serve as baseline information with which future environmental impact assessment of anthropogenic activities could be progressively monitored in the area.

\section{Acknowledgment}

Authors are grateful to Tertiary Education Trust Fund
(TETFund), Nigeria for providing research grant to carry out this study.

\section{Conflict of Interest}

Authors declare that there are no conflicts of interest.

\section{References}

1. Mgbemena, N. M. (2016). Physicochemical and bacteriological analysis of borehole waters in Owerri north L.G.A. Imo State, Nigeria. J. Chem. Soc. Nigeria, 41(1), $99-104$.

2. Anzene, S. J. \& Aremu, M. O. (2007). Quality and antiseptic properties assessment of indigenous black soap produced in Nasarawa State, Nigeria. J. Eng. \& Appl. Sci., 2(8), $1297-1300$

3. Umo, A. E. \& Okoye, C. O. B. (2006). Quality of borehole water in Nsukka Area, Enugu State, Nigeria. Annals of Natural Sciences, 6(2), $121-127$.

4. Geldreich, C. N. (2005). The bacteriology of water. Topley Wilson's microbiology and microbial infections. $9^{\text {th }}$ edn. London, Holder Arnold, pp. $57-63$.

5. Adeyeye, E. I., Akinyugha, N. J., Fesobi, M. E. \& Tenabe, V. O. (1996). Determination of some metals in Claria gariepinus (Cuvier and Vallenciennes), Cyprinus carpio (L) and Oreochromis nibticus (L) fishes in a polyculture fresh water pond and their environments. Aquaculture, 147, 205 - 214

6. Aremu, M. O., Atolaiye, B. O. \& Labaran, L. (2010). Environmental implication of metal concentrations in soil, plant foods and pond in area around the derelict Udege mines of Nasarawa State, Nigeria. Bulletin Chem. Soc. Ethiopia, 24(3), $351-360$.

7. Smith, C. J., Hopmans, P. \& Cook, F. J. (1996). Accumulation of $\mathrm{Cr}, \mathrm{Pb}, \mathrm{Cu}, \mathrm{Ni}, \mathrm{Zn}$ and $\mathrm{Cd}$ in soil following irrigation with untreated Urban effluents in Australia. Environmental Pollution, 94(3), 317 - 323.

8. Aremu, M. O., Olonisakin, A. \& Ahmed, S. A. (2006). Assessment of heavy metal content in some selected agricultural products planted along some roads in Nasarawa State, Nigeria. J. Eng. \& Appl. Sci., 1(3), 199 $-204$.

9. Ademoroti, C. M. A. (1996). Environmental Chemisry Toxicology. Foludex Press Ltd, Ibadan, pp. $180-184$.

10. Aremu, M. O., Gav, B. L., Opaluwa, O. D., Atolaiye, B. O., Sangari, D. U. \& Madu, P. C. (2011). Metal concentrations of sediments and water from Rivers Doma, Farinruwa and Mada in Nasarawa State, Nigeria. J. Env. Chem. \& Ecotox., 3(9), $244-251$.

11. Aiyesanmi, A. F. (2006). Baseline concentration of heavy metals in water samples from rivers within Okitipupa, southeast belt of the Nigerian bitumen field. J. Chem. Soc. Nigeria., 31(1\&2), 30 - 37.

12. Atolaiye, B. O., Aremu, M. O., Shaggye, D. \& Pennap, G. R. I. (2006). Distribution and concentration of some mineral elements in soil sediment, ambient water and the body part of Clarias gariepinus and Tilapia quineensis fishes in River Tammah, Nasarawa State, Nigeria Current World Env., 1(2), 95 - 100.

13. Davis, B. J. \& Jixiang, G. (2000). Airborne particles study in five cities of China atmosphere. Environ., 34, $703-711$.

14. American Public Health Association (APHA) (1992) Standard Methods for the Examinations of Water and Wastewaters, $18^{\text {th }}$ edn., Washington, DC.

15. United States Environmental Protection Agency (USEPA) (2002). Current Drinking Water Standards. Office of Groundwater and Drinking Water. Government Printing Office, Washington DC.

16. United Nations (UN) (1998). Global Opportunities for Reducing use of Lead Gasoline, IOMC/UNEP/CHEMICALS/98/9: Switzerland. 
Ground Water and River Quality Assessment for Some Heavy Metals and Physicochemical Parameters in Wukari Town, Taraba State, Nigeria

17. Hutton, M. (1987). In: Lead, Mercury, Cadmium and Arsenic in the Environment. Hutchinson, T. C. \& Mecma, K. M. (Eds.), Wiley, UK, pp. $85-94$.

18. FME, Federal Ministry of Environment (2001). National Guidelines and Standards for Water Quality in Nigeria, FME, Nigeria.

19. Aiyesanmi, A. F. (2006). Baseline concentration of heavy metals in water samples from rivers within Okitipupa, Southwest belt of the Nigerian bitumen field, Nigeria. J. Chem. Soc., 31(1-2), 30-37.

20. Aremu, M. O. \& Inajoh, A. (2007). Assessment of elemental contaminants in water and selected sea-foods from River Benue, Nigeria. Curr. Would Environ., 2(2), $167-173$.

21. Kakulu, S. E. \& Osibanjo, O. (1988). Trace heavy metal pollution status in sediment of the Niger Delta Area of Nigeria. J. Chem. Soc. Nig., 13, $9-15$.

22. Okoye, B. C. O. (1991). Heavy metals and organisms in the Lagos Lagoon. Int. J. Environ. Studies, 37, $285-$ 292.

23. Wheby, M. S. (1974). Synthetic effects of iron deficiency. In: Iron, Crosby, W. H. (ed.), Midicom Inc., New York, p. 39
24. Bender, A. (1992). Meat and Meat Products in Human Nutrition in Developing Countries. FAO Food and Nutrition Paper 53, FAO, Rome, Italy, pp. 46 - 47.

25. Eisler, R. (1993). Zinc hazard to fish, wildlife and invertebrates. A synoptic review. US fish and wildlife service, biological report 10. Publication Unit, USFWS, Washington, DC, 20240.

26. Aremu, M. O., Sangari, D. U. Musa, B. Z. and Chaanda, M. S. (2008). Assessment of groundwater and stream quality for trace metals and physicochemical contaminants in Toto local government area of Nasarawa State, Nigeria. Int. J. Chem. Sci., 1(1), $8-19$.

27. WHO (2004). World Health Organization Guidelines for Drinking Water Quality, $3^{\text {rd }}$ edition, Vol. 1, Geneva.

28. Aremu, M. O., Gav, B. L., Opaluwa, O. D., Atolaiye, B. O., Madu, P. C. and Sangari, D. U. (2011). Assessment of physicochemical contaminants in waters and fishes from selected rivers in Nasarawa State, Nigeria. Res. $J$. Chem. Sci., 1(4), 6-17.

29. Templeton, R. G. (1984). Freshwater Fisheries Management Fishing, New Books Ltd., Pamham, Survey, p. 183 